\title{
Dobór materiałów wiążących w celu poprawy wytrzymałości kamieni cementowych z zaczynów emulsyjnych
}

\section{Selection of binding materials to improve the mechanical strength of cement stones from emulsion slurry}

\author{
Łukasz Kut \\ Instytut Nafty i Gazu - Państwowy Instytut Badawczy
}

\begin{abstract}
STRESZCZENIE: Technologia uszczelniania przestrzeni pierścieniowej pomiędzy kolumną rur okładzinowych a ścianą otworu wiertniczego oparta jest głównie na zaczynach cementowych lub cementowo-lateksowych na bazie wody słodkiej lub wody zasolonej. Takie zaczyny uszczelniające sprawdzają się podczas zabiegów cementacyjnych w otworach odwiercanych płuczką wodnodyspersyjną. Jednak coraz częściej otwory wiertnicze wykonywane są przy użyciu płuczki inwersyjnej (olejowodyspersyjnej), np. Kutno, Tyczyn, Kramarzówka. Płuczki te mogą być stosowane do wiercenia otworów w prawie każdych warunkach geologicznych. Użycie tego typu płuczki niesie wiele pozytywnych aspektów, jednak zdarzają się też negatywne. Jedną z niedogodności jest pozostawianie na ścianach otworu wiertniczego trudnego do usunięcia osadu, co w konsekwencji może mieć wpływ na nieskuteczne uszczelnienie kolumny rur okładzinowych. Obecność tego rodzaju płuczki wiertniczej i jej osadów w otworze podczas uszczelniania kolumny rur okładzinowych wymaga zastosowania specjalnie opracowanych zaczynów cementowych z dodatkiem oleju. Pierwsze próby sporządzenia zaczynów cementowych przygotowanych na bazie płynu woda w oleju wykazały, że nie jest to łatwe do osiągnięcia, ale jednak możliwe. Otrzymano zaczyny cementowe o dobrych parametrach reologicznych, natomiast parametry mechaniczne kamieni cementowych były niskie. Celem badań laboratoryjnych było więc opracowanie zaczynów cementowych sporządzonych na bazie różnych spoiw wiążących do uszczelniania kolumn rur okładzinowych po zastosowaniu płuczki inwersyjnej, z których można by uzyskać kamienie cementowe o podwyższonych parametrach wytrzymałościowych. Obecność oleju w składzie zaczynu cementowego może wpłynąć na jego większą kompatybilność z pozostawionymi na ścianach otworu osadami, a co za tym idzie - także na skuteczniejsze uszczelnienie przestrzeni pierścieniowej. Jako cieczy zarobowej użyto wody wodociągowej, do której dodawano kolejno: środek powierzchniowo czynny (SPC) oraz cement, mieszaninę cementów lub cementu z innym spoiwem. Po ujednorodnieniu mieszaniny dodawano do niej olej wymieszany z emulgatorem. Po połączeniu wszystkich składników zaczyn cementowy mieszano przez 30 minut, a następnie wykonywano pomiary laboratoryjne: gęstości, parametrów reologicznych, filtracji, czasu wiązania, elektrycznej stabilności emulsyjnej. Z wybranych zaczynów sporządzono próbki kamieni cementowych. Próbki te utwardzano i przetrzymywano w dwóch różnych temperaturach: $25^{\circ} \mathrm{C}$ oraz $120^{\circ} \mathrm{C}$. Otrzymane kamienie cementowe poddano badaniu: wytrzymałości na ściskanie, przyczepności do rur stalowych, porowatości, przepuszczalności dla gazu. Badania wykazały, że zastosowanie cementów glinowo-wapniowych lub ich mieszanin z innym spoiwem wpłynęło pozytywnie na parametry technologiczne zaczynów i kamieni cementowych. Użycie tego rodzaju cementów i spoiw doprowadziło do obniżenia filtracji oraz wzrostu elektrycznej stabilności emulsyjnej zaczynów cementowych w porównaniu do powszechnie stosowanych cementów portlandzkich. Ujednorodnienie mieszaniny oraz wspólne łączenie się poszczególnych dodatków nie stwarzało większych trudności. Również otrzymane kamienie cementowe odznaczały się dobrymi parametrami mechanicznymi (Maghrabi et al., 2011; Dębińska, 2012; Kremieniewski, 2012, 2013; Vipulanandan i Krishnamoorti, 2013).
\end{abstract}

Słowa kluczowe: zaczyn cementowy, zaczyn emulsyjny, emulsja typu „W/O”, płuczka inwersyjna, cement glinowo-wapniowy, kamień cementowy, parametry mechaniczne, parametry technologiczne.

ABSTRACT: Sealing technology during the sealing of the annular space between the casing column and the borehole wall mainly used cement slurries or latex cement slurries based on freshwater or brackish water. Such cement slurries work well during cementation operations in holes drilled with water-based drilling mud. In the oil industry, more and more often boreholes are drilled using inversion mud (oil-based mud), e.g. Kutno, Tyczyn, Kramarzówka. These muds can be used to drill holes in almost any geological conditions. The use of this type of mud has many advantages and benefits, however, there are also negative aspects. One of the disadvantages is the difficulty of removing mud cake on the walls of the borehole, which may affect the ineffective sealing of the casing column. The presence of this type of drilling mud and its filter cakes in the hole, when sealing the column of casing pipes, requires the use of specially developed cement slurries with the addition of oil. First attempts to prepare cement slurries based on liquid water-in-oil showed

Autor do korespondencji: Ł. Kut, e-mail: lukasz.kut@inig.pl

Artykuł nadesłano do Redakcji: 04.12.2019 r. Zatwierdzono do druku: 05.03.2020 r. 
that this is not easy to achieve but not impossible. Cement slurries with good technological parameters were obtained, however, the mechanical parameters of cement stones were low. The aim of the presented research was to develop cement slurries based on various binders, used to seal the casing columns after the use of an invert emulsion drilling mud, from which we will obtain stones with increased strength parameters. The presence of oil in the composition of the cement slurry may affect its greater compatibility with mud cake on the walls of the borehole and more effective sealing of the annular space. The freshwater played the role of the slurry. The dispersant, surfactant, cement, a mixture of types of cement or cement with another binder were then added. The oil mixed with the emulsifier was added after homogenizing the mixture. Once all the components were combined, the cement slurry was mixed for 30 minutes and their technological parameters such as density, rheological parameters, filtration, setting time and electrical stability were examined. Cement stone test samples were prepared from selected cement slurries. These samples were cured and hydrated at two different temperatures: $25^{\circ} \mathrm{C}$ and $120^{\circ} \mathrm{C}$. The compressive strength and adhesion to steel pipes tests, porosity and gas permeability were performed for the obtained cement stones. The tests showed that the use of calcium-aluminum types of cement or their mixtures with other binders had a positive effect on the technological parameters of the slurries and cement stones. The use of this type of cement and binders resulted in a decrease of filtration and an increase in the electrical emulsion stability of cement slurries compared to the Portland types of cement. The homogeneity of the mixture and the combination of additives did not pose major difficulties. The obtained cement stones had good mechanical parameters (Maghrabi et al., 2011; Dębińska, 2012; Kremieniewski, 2012, 2013; Vipulanandan and Krishnamoorti, 2013).

Key words: cement slurry, emulsion slurry, W/O emulsion, invert emulsion drilling mud, calcium-aluminum cement, cement stone, mechanical parameters, technological parameters.

\section{Wprowadzenie}

Wiercenie otworów odbywa się przy udziale różnych rodzajów płuczek wiertniczych, zarówno wodnodyspersyjnych, jak i coraz częściej płuczek inwersyjnych (olejowodyspersyjnych). Na parametry technologiczne oraz rodzaj zastosowanej płuczki wiertniczej wpływ mają między innymi trajektoria, głębokość otworu oraz panujące temperatura i ciśnienie.

Wszystkie te czynniki mają również znaczenie podczas opracowywania i sporządzania zaczynów cementowych, które powinny charakteryzować się odpowiednią gęstością, reologią, zerowym odstojem wody, odpowiednią filtracją i optymalnym czasem gęstnienia w celu ich bezpiecznego zatłoczenia do otworu wiertniczego. Właściwości zaczynów cementowych są istotne podczas zabiegów uszczelniania kolumn rur okładzinowych, ale równie ważne są parametry mechaniczne powstałego z nich kamienia cementowego. Kamień cementowy powinien tworzyć w przestrzeni pozarurowej zbitą i szczelną barierę odporną na działające w otworze obciążenia (między innymi ściskające, zginające i inne) oraz być nieprzepuszczalny dla wszelkich dopływających mediów.

Efektywne wypełnienie przestrzeni pierścieniowej zaczynem cementowym możliwe będzie, gdy uzyska się pełne wyparcie z niej płuczki. Zostanie to osiągnięte dzięki zapewnieniu określonych prędkości przepływu zaczynu poza rurami i optymalnych właściwości reologicznych poszczególnych cieczy tłoczonych $\mathrm{w}$ trakcie zabiegu cementowania. W praktyce zaczyny cementowe traktuje się jako ciecz binghamowską, dla której określa się lepkość plastyczną i granicę płynięcia, natomiast dla zaczynów rozpatrywanych przy użyciu modelu Ostwalda de Waele’a podaje się współczynnik konsystencji oraz wskaźnik płynięcia. Jednak na podstawie badań można powiedzieć, że zaczyny najlepiej opisywane są modelem Herschela-Bulkleya.

Uszczelnienie otworów wiertniczych, do których wiercenia stosowano płuczki olejowodyspersyjne, wymaga użycia emulsyjnych zaczynów cementowych z dodatkiem oleju.

Emulsjami ogólnie określany jest układ dwóch niemieszających się ze sobą oraz wzajemnie nierozpuszczalnych cieczy, z których jedna jest rozproszona w drugiej w postaci drobnych kropelek. W przypadku zmieszania dwóch cieczy wzajemnie rozpuszczalnych, np. wody i alkoholu, nie powstaje emulsja, a roztwór. Emulsje zatem otrzymuje się poprzez wymieszanie wzajemnie nierozpuszczalnych cieczy, np. benzenu lub toluenu z wodą. Przez energiczne wytrząsanie uzyskuje się emulsję, lecz przerwanie wytrząsania powoduje w krótkim czasie rozdzielenie obu cieczy odpowiednio do ich gęstości.

Badane zaczyny cementowe zarabiano przy użyciu emulsji wykonanej z dwóch wzajemnie niemieszających się cieczy, tj. wody i oleju. Obecność oleju w składzie zaczynu cementowego może wpłynąć na jego większą kompatybilność z pozostawionymi na ścianach otworu osadami, a co za tym idzie - także na skuteczniejsze uszczelnienie przestrzeni pierścieniowej. Również otrzymane kamienie cementowe dzięki wykorzystaniu różnych rodzajów cementów i spoiw powinny odznaczać się dobrymi parametrami mechanicznymi.

Przeprowadzone badania i uzyskane wyniki przedstawiają wpływ zastosowania różnych spoiw wiążących na parametry zaczynów i kamieni cementowych opracowanych na bazie wody i oleju. Celem badań był dobór receptury umożliwiającej skuteczne uszczelnienie przestrzeni pierścieniowej, w której będą występować ewentualne osady pozostawione przez płuczkę inwersyjną (Giergiczny, 2003; Kurdowski, 2010; Kut, 2011; Jasiński, 2012; Kurca et al., 2013; Fernandez et al., 2014; Li et al., 2016). 


\section{Badania laboratoryjne}

Badaniom laboratoryjnym poddano różne składy zaczynów cementowych, zaś w artykule zamieszczono wyniki badań wybranych składów zaczynów, jak i otrzymanych z nich kamieni cementowych sporządzanych na bazie wody i oleju, które mogłyby posłużyć do uszczelniania kolumn rur okładzinowych po wcześniejszym zastosowaniu w otworze płuczki inwersyjnej. Głównym celem badań było otrzymanie kamieni cementowych o podwyższonych parametrach mechanicznych dzięki zastosowaniu różnych cementów i spoiw hydraulicznych. Początkowe badania polegały na doborze ilościowym i jakościowym składników w celu otrzymania jednorodnej mieszaniny zaczynu na bazie emulsji oleju z wodą posiadającej zdolność mieszania i przetłaczania. Kolejny etap to badania parametrów zaczynów cementowych, tj. filtracji, gęstości, reologii, czasu wiązania i elektrycznej stabilności emulsyjnej, oraz parametrów kamieni cementowych otrzymanych $\mathrm{z}$ wybranych receptur. $\mathrm{W}$ badaniach określono również wytrzymałość kamieni cementowych na ściskanie, ich przyczepność do rur stalowych oraz porowatość i przepuszczalność dla gazu.

Zaczyny z dodatkiem oleju wykonano na bazie trzech różnych cementów glinowo-wapniowych, cementu wiertniczego oraz z dodatkiem trzech różnych spoiw. Do badań wykorzystano olej mineralny charakteryzujący się niską lepkością, temperaturą wrzenia powyżej $200^{\circ} \mathrm{C}$ i niską zawartością związków aromatycznych - poniżej 0,2\%. Wybrano olej najczęściej wykorzystywany podczas sporządzania płuczek inwersyjnych. Badania prowadzono dla dwóch temperatur $25^{\circ} \mathrm{C}$ i $120^{\circ} \mathrm{C}$ (Demirdal i Cunha, 2007; Kirca et al., 2013; Alford et al., 2014).

Po sporządzeniu zaczynów cementowych zmierzono ich parametry reologiczne, a następnie $z$ wybranych składów wykonano próbki kamieni cementowych. Próbki utwardzano w określonych warunkach temperatury i ciśnienia (warunki otworopodobne). Następnie umieszczano je w autoklawach wykonanych ze stali nierdzewnej i przez cały okres sezonowania przetrzymywano w cieplarce. Otrzymane kamienie cementowe po założonym czasie poddawano badaniom laboratoryjnym.

W tabelach od 1 do 5 i na rysunkach od 1 do 6 przedstawiono szczegółowe wyniki badań parametrów technologicznych zaczynów i kamieni cementowych. Wybrano składy zaczynów, z których uzyskane kamienie cementowe posiadały najlepsze parametry technologiczne.

Niepewność otrzymanych wyników pomiarów zaprezentowanych poniżej oznaczono na podstawie klasy dokładności urządzeń pomiarowych na poziomie: dla pomiarów reologicznych $-0,2 \%$, dla pomiarów wytrzymałości na ściskanie oraz przyczepności do rur $-0,4 \%$.

W tabeli 1 zestawiono wyniki parametrów 8 wybranych zaczynów cementowych opracowanych na bazie wody i oleju. Zaczyny cementowe sporządzone na bazie cementów glinowowapniowych charakteryzowały się gęstością 1,625-1,675 g/ $\mathrm{cm}^{3}$. Wszystkie zaczyny przygotowane na tych cementach posiadały niską filtrację: 3,0-15,0 $\mathrm{cm}^{3} / 30 \mathrm{~min}$. Zaczyny cementowe wykonane na bazie cementów glinowych posiadały elektryczną stabilność emulsyjną (ES) mieszczącą się w przedziale od $32 \mathrm{~V}$ do $90 \mathrm{~V}$. Wyższe wskaźniki ES miały wpływ na dłuższe czasy wiązania zaczynów cementowych. Wraz ze wzrostem elektrycznej stabilności wzrastać powinna również kompatybilność danego zaczynu cementowego z płuczką inwersyjną.

Ostatnie dwa zaczyny cementowe sporządzono na bazie cementu wiertniczego G, powszechnie stosowanego w przemyśle naftowym. Posiadały one gęstość zbliżoną do $1,69 \mathrm{~g} / \mathrm{cm}^{3}$. Zaczyny wykonane na bazie cementu wiertniczego posiadały

Tabela 1. Parametry zaczynów cementowych z dodatkiem oleju i 100\% cementu

Table 1. Parameters of cement slurries with the addition of oil and $100 \%$ cement

\begin{tabular}{|c|c|c|c|c|c|c|c|c|c|c|}
\hline \multirow{2}{*}{ Sklad } & \multirow{2}{*}{ Cement } & \multirow{2}{*}{$\mathbf{w} / \mathbf{c}^{*}$} & $\mathbf{S P C}^{*}$ & Olej & Emulgator & \multirow{2}{*}{$\begin{array}{c}\text { Gęstość } \\
{\left[\mathrm{g} / \mathrm{cm}^{3}\right]}\end{array}$} & \multirow{2}{*}{$\begin{array}{c}\text { Filtracja } \\
{\left[\mathrm{cm}^{3}\right]} \\
\end{array}$} & $\mathbf{P W}^{*}$ & $\mathbf{K} \mathbf{W}^{*}$ & \multirow{2}{*}{$\begin{array}{c}\text { Wskaźnik ES } \\
{[\mathrm{V}]} \\
\end{array}$} \\
\hline & & & \multicolumn{3}{|c|}{ [\%] } & & & \multicolumn{2}{|c|}{ [dni] } & \\
\hline 2 & G40 & 0,38 & 0,2 & 65,0 & 6,0 & 1,675 & 6 & 4 & 6 & 38 \\
\hline 3 & G40 & 0,38 & 0,2 & 75,0 & 6,0 & 1,670 & 15 & 4 & 5 & 32 \\
\hline 5 & G50 & 0,38 & 0,2 & 65,0 & 6,0 & 1,650 & 4 & 5 & 11 & 90 \\
\hline 6 & G50 & 0,38 & 0,2 & 75,0 & 6,0 & 1,645 & 8 & 5 & 6 & 64 \\
\hline 9 & G70 & 0,38 & 0,2 & 65,0 & 6,0 & 1,630 & 3 & 5 & 6 & 76 \\
\hline 10 & G70 & 0,38 & 0,2 & 75,0 & 6,0 & 1,625 & 5 & 4 & 5 & 50 \\
\hline 13 & G & 0,38 & 0,2 & 65,0 & 6,0 & 1,690 & 64 & 2 & 4 & 17 \\
\hline 14 & G & 0,38 & 0,2 & 75,0 & 6,0 & 1,685 & 76 & 2 & 3 & 15 \\
\hline
\end{tabular}

G40 - glinowy 40; G50 - glinowy 50; G70 - glinowy 70, G - cement wiertniczy; w/c - stosunek wody do suchego cementu; PW - początek wiązania; KW - koniec wiązania; SPC - środek powierzchniowo czynny, dodawany w stosunku do ilości wody; olej dodawany w stosunku do ilości wody; emulgator dodawany do ilości oleju 
wyższą filtrację, powyżej $64,0 \mathrm{~cm}^{3} / 30 \mathrm{~min}$. Zastosowanie w zaczynach cementowych tego rodzaju cementu doprowadziło również do obniżenia ich elektrycznej stabilności emulsyjnej. Niższy wskaźnik ES wpłynął na krótsze czasy wiązania zaczynów cementowych.

W tabeli 2 zamieszczono wyniki badań laboratoryjnych zaczynów cementowych z dodatkiem oleju i mieszaniny różnych spoiw wiążących. Zaczyny cementowe sporządzono na bazie cementów glinowo-wapniowych $(80 \%, 90 \%)$ z dodatkiem żużla, hematytu lub mikrocementu $(10 \%, 20 \%)$. Większość zaczynów posiadała gęstość w zakresie $1,63-1,65 \mathrm{~g} / \mathrm{cm}^{3}$, nieznacznie wyższą gęstością cechował się natomiast skład z dodatkiem hematytu $-1,67 \mathrm{~g} / \mathrm{cm}^{3}$.

Wszystkie zaczyny posiadały niską filtrację, nieprzekraczającą $5,5 \mathrm{~cm}^{3} / 30 \mathrm{~min}$. Zastosowanie w zaczynach cementowych domieszek żużla, hematytu lub mikrocementu nieznacznie wpłynęło na obniżenie ich elektrycznej stabilności emulsyjnej w porównaniu do zaczynów sporządzonych na 100\% cementu. Wskaźnik ES wynosił od $25 \mathrm{~V}$ do $50 \mathrm{~V}$ i był niższy o około 30-40 V w porównaniu do zaczynów wykonanych na samym cemencie glinowo-wapniowym.

Parametry reologiczne wybranych zaczynów cementowych sporządzonych na bazie cementu glinowo-wapniowego lub jego mieszaniny z innym dodatkiem przedstawiono w tabeli 3, zaś na rysunkach 1 i 2 zaprezentowano modele reologiczne Herschela-Bulkleya dla wybranych składów. Współczynnik korelacji dla wszystkich składów wahał się od 0,992 do 1,000, a więc były to korelacje bardzo wysokie lub pełne. Na podstawie tych samych składów w kolejnych tabelach i na rysunkach przedstawione zostały wyniki badań kamieni cementowych uzyskanych z tych zaczynów.

W tabeli 4 oraz graficznie na rysunkach 3 i 4 przedstawiono wyniki badań wytrzymałości na ściskanie otrzymane dla próbek kamieni cementowych sezonowanych $\mathrm{w}$ dwóch różnych temperaturach: $25^{\circ} \mathrm{C}$ i $120^{\circ} \mathrm{C}$. Zgodnie z wynikami badań po 7 dniach wytrzymałości na ściskanie dla wybranych składów

Tabela 2. Parametry zaczynów cementowych z dodatkiem oleju i mieszaniny spoiw wiążących

Table 2. Parameters of cement slurries with the addition of oil and a mixture of binding materials

\begin{tabular}{|c|c|c|c|c|c|c|c|c|c|c|c|}
\hline \multirow[t]{2}{*}{ Skład } & $\begin{array}{l}\text { Cement } \\
\text { glinowy }\end{array}$ & $\mathbf{S H}^{*}$ & \multirow[t]{2}{*}{$\mathbf{w} / \mathbf{c}$} & SPC & Olej & Emulgator & \multirow{2}{*}{$\begin{array}{c}\text { Gęstość } \\
{\left[\mathrm{g} / \mathrm{cm}^{3}\right]}\end{array}$} & \multirow{2}{*}{$\begin{array}{c}\text { Filtracja } \\
{\left[\mathrm{cm}^{3}\right]}\end{array}$} & PW & KW & \multirow{2}{*}{$\begin{array}{c}\text { Wskaźnik } \\
\text { ES } \\
{[\mathrm{V}]}\end{array}$} \\
\hline & \multicolumn{2}{|c|}{$[\%]$} & & \multicolumn{3}{|c|}{$[\%]$} & & & \multicolumn{2}{|c|}{ [dni] } & \\
\hline 27 & $\mathrm{G} 70-80$ & $M-20$ & 0,38 & 0,2 & 65,0 & 6,0 & 1,645 & 5,0 & 4 & 5 & 41 \\
\hline 29 & $\mathrm{G} 70-90$ & $M-10$ & 0,38 & 0,2 & 65,0 & 6,0 & 1,640 & 4,5 & 4 & 5 & 45 \\
\hline 31 & $\mathrm{G} 70-90$ & $M-10$ & 0,38 & $0,2_{\mathrm{B}}$ & 65,0 & 6,0 & 1,640 & 4,5 & 3 & 4 & 43 \\
\hline 32 & G50 - 90 & $M-10$ & 0,38 & 0,2 & 65,0 & 6,0 & 1,650 & 5,0 & 5 & 7 & 50 \\
\hline 35 & $\mathrm{G} 70-80$ & $\mathrm{H}-20$ & 0,38 & 0,2 & 65,0 & 6,0 & 1,670 & 5,0 & 2 & 3 & 25 \\
\hline 39 & $\mathrm{G} 70-80$ & $\dot{Z}-20$ & 0,38 & 0,2 & 65,0 & 6,0 & 1,635 & 5,5 & 5 & 6 & 38 \\
\hline 40 & $\mathrm{G} 70-90$ & $\dot{Z}-10$ & 0,38 & 0,2 & 65,0 & 6,0 & 1,630 & 5,0 & 3 & 4 & 42 \\
\hline
\end{tabular}

* SH - spoiwo hydrauliczne ( $\dot{\mathrm{Z}}$ - żużel, H - hematyt, M - mikrocement)

Tabela 3. Parametry reologiczne wybranych zaczynów cementowych

Table 3. Rheological parameters of selected cement slurries

\begin{tabular}{|c|c|c|c|c|c|c|c|c|c|c|}
\hline \multirow{2}{*}{ Skład $[\mathrm{Obr} / \mathrm{min}]$} & \multicolumn{8}{|c|}{ Odczyty $z$ aparatu FANN typ 900} & \multirow{2}{*}{$\begin{array}{c}\text { Lepkość plastyczna } \\
{[\mathrm{mPa} \cdot \mathrm{s}]}\end{array}$} & \multirow{2}{*}{$\begin{array}{c}\text { Granica płynięcia } \\
{[\mathrm{Pa}]}\end{array}$} \\
\hline & 600 & 300 & 200 & 100 & 60 & 30 & 6 & 3 & & \\
\hline 9 & $>350$ & 297 & 217 & 127 & 87 & 52 & 18 & 12 & 255,0 & 20,2 \\
\hline 10 & 324 & 178 & 126 & 71 & 47 & 27 & 8 & 6 & 160,5 & 8,4 \\
\hline 27 & $>350$ & 223 & 159 & 92 & 60 & 36 & 11 & 8 & 196,5 & 12,7 \\
\hline 29 & $>350$ & 270 & 198 & 117 & 79 & 48 & 16 & 11 & 229,5 & 19,4 \\
\hline 31 & $>350$ & 272 & 204 & 121 & 83 & 50 & 17 & 12 & 226,5 & 21,8 \\
\hline 32 & $>350$ & 255 & 190 & 115 & 80 & 50 & 18 & 12 & 210,0 & 21,6 \\
\hline 35 & 336 & 193 & 140 & 81 & 53 & 30 & 8 & 6 & 168,0 & 12,0 \\
\hline 39 & $>350$ & 252 & 180 & 103 & 68 & 40 & 12 & 9 & 223,5 & 13,7 \\
\hline 40 & $>350$ & 280 & 201 & 116 & 78 & 44 & 12 & 9 & 246,0 & 16,3 \\
\hline
\end{tabular}




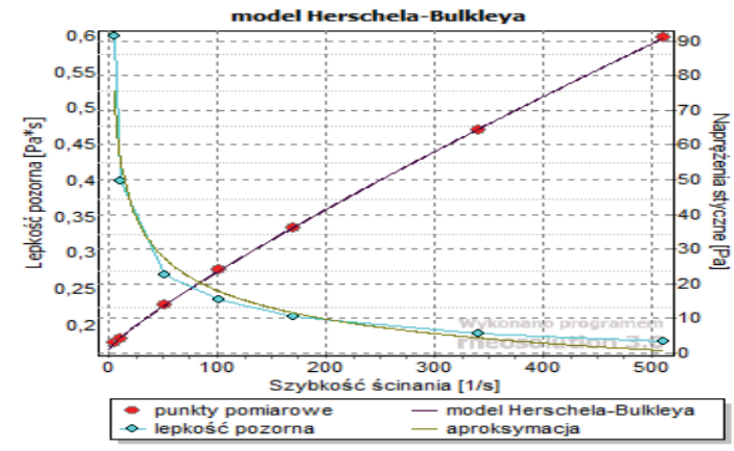

Rys. 1. Model Herschela-Bulkleya dla zaczynu cementowego $\mathrm{nr} 10$

Fig. 1. Herschel-Bulkley model for cement slurry No. 10

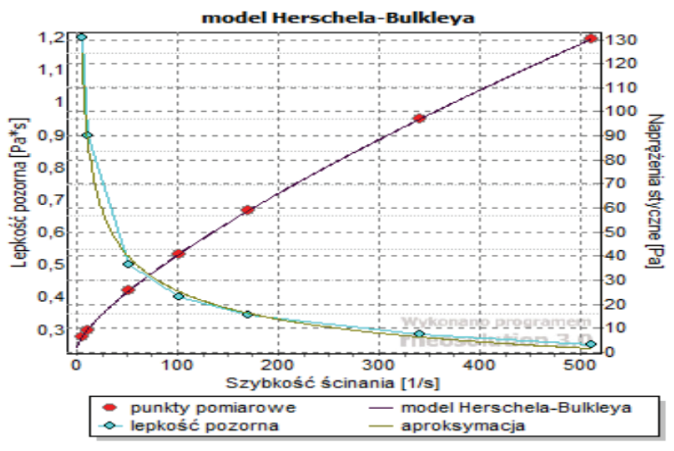

Rys. 2. Model Herschela-Bulkleya dla zaczynu cementowego $\mathrm{nr} 32$

Fig. 2. Herschel-Bulkley model for cement slurry No. 32

Tabela 4. Wytrzymałość kamieni cementowych na ściskanie

Table 4. Compressive strength of cement stones

\begin{tabular}{|c|c|c|c||c|c|c|}
\hline \multirow{3}{*}{ Skład } & \multicolumn{5}{|c|}{ Wytrzymalość na ściskanie [MPa] } \\
\cline { 2 - 7 } & \multicolumn{3}{|c|}{ Temperatura 25 ${ }^{\circ} \mathbf{C}$} & \multicolumn{3}{c|}{ Temperatura 120 ${ }^{\circ}$} \\
\cline { 2 - 7 } & po 7 dniach & po 14 dniach & po 28 dniach & po 7 dniach & po 14 dniach & po 28 dniach \\
\hline \hline 9 & 12,7 & 16,5 & 17,5 & 9,1 & 11,8 & 14,9 \\
\hline 10 & 13,4 & 15,1 & 11,8 & 9,7 & 9,9 & 10,4 \\
\hline 27 & 11,4 & 7,5 & 12,9 & 9,9 & 10,2 & 13,6 \\
\hline 29 & 10,9 & 8,8 & 17,0 & 8,8 & 9,6 & 10,6 \\
\hline 31 & 14,3 & 12,9 & 10,1 & 6,0 & 6,4 & 5,8 \\
\hline 32 & 9,1 & 8,0 & 4,9 & 14,5 & 18,6 & 16,4 \\
\hline 35 & 8,9 & 1,5 & 16,2 & 12,1 & 10,6 & 7,2 \\
\hline 39 & 9,6 & 6,8 & 5,7 & 8,0 & 7,5 & 9,7 \\
\hline 40 & 10,4 & 9,5 & 13,5 & 11,8 & 9,8 & 9,0 \\
\hline
\end{tabular}

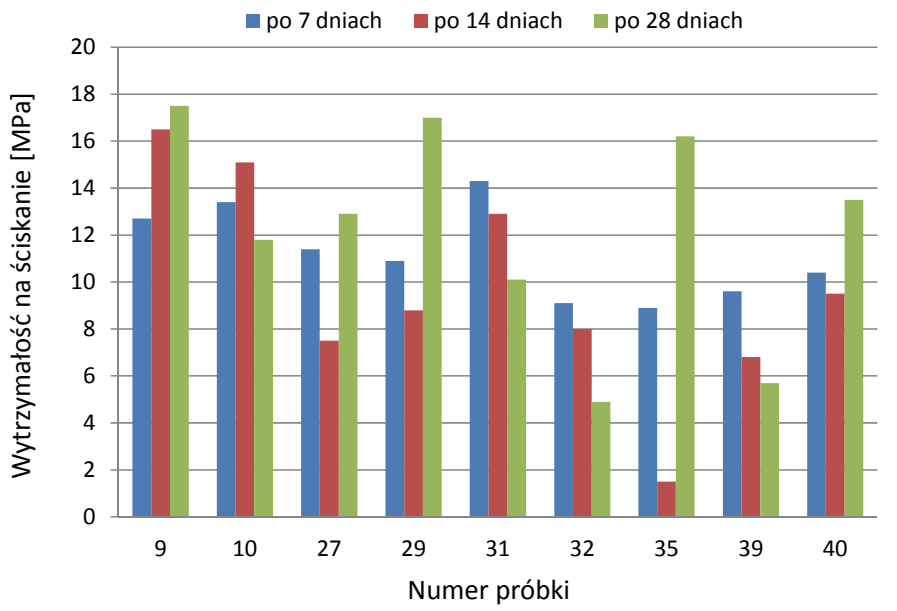

Rys. 3. Wytrzymałość kamieni cementowych na ściskanie dla temperatury $25^{\circ} \mathrm{C}$

Fig. 3. Compressive strength of cement stones at $25^{\circ} \mathrm{C}$

dla temperatury $25^{\circ} \mathrm{C}$ wynosiły od $8,9 \mathrm{MPa}$ do $14,3 \mathrm{MPa}$, najmocniejsza była próbka nr 31 z zawartością $90 \%$ cementu glinowo-wapniowego (G70) i 10\% mikrocementu. Po tym samym czasie spośród próbek sezonowanych $\mathrm{w} 120^{\circ} \mathrm{C}$ najmocniejsza okazała się ta, która również zawierała $90 \%$ cementu

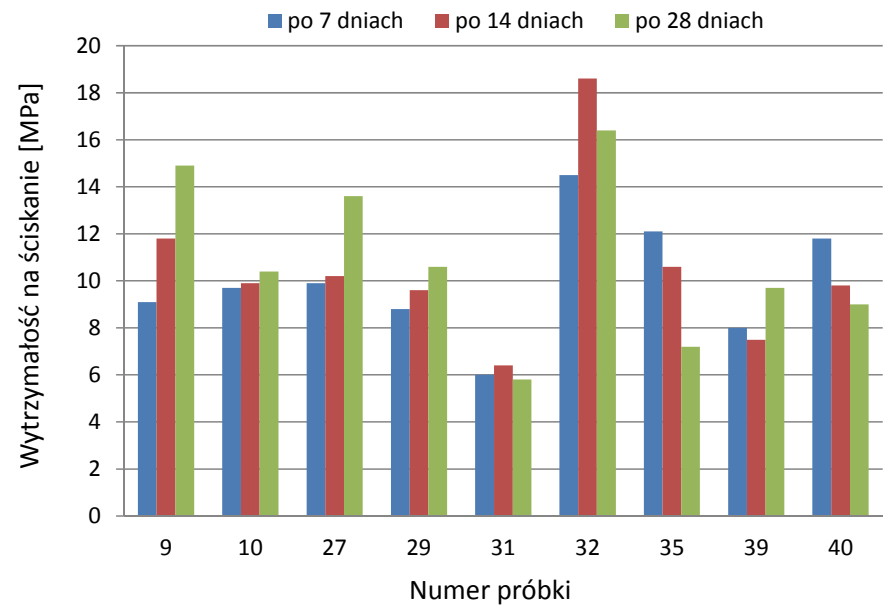

Rys. 4. Wytrzymałość kamieni cementowych na ściskanie dla temperatury $120^{\circ} \mathrm{C}$

Fig. 4. Compressive strength of cement stones at $120^{\circ} \mathrm{C}$

glinowo-wapniowego, jednak oznaczonego G50, oraz 10\% mikrocementu, jej wytrzymałość wyniosła 14,5 MPa (próbka nr 32).

Po 28 dniach najwyższe wytrzymałości na ściskanie dla temperatury $25^{\circ} \mathrm{C}$ posiadały próbki nr 9,29 oraz 35 . Wszystkie 
zawierały cement G70. Pierwsza z nich, sporządzona na bazie samego cementu glinowo-wapniowego $(100 \%)$, posiadała wytrzymałość $17,5 \mathrm{MPa}$, w przypadku drugiej, z domieszką mikrocementu (10\%), wytrzymałość wyniosła 17,0 MPa, zaś ostatnia, z dodatkiem hematytu (20\%), miała wytrzymałość $16,2 \mathrm{MPa}$. W przypadku temperatury $120^{\circ} \mathrm{C}$ najmocniejsze okazały się kamienie cementowe wykonane na samym cemencie glinowo-wapniowym G70 (próbka nr 9), o wytrzymałości 14,9 MPa, oraz na mieszaninie cementu glinowego G50 i mikrocementu (w stosunku 90\% do 10\%), o wytrzymałości 16,4 MPa (próbka nr 32).

Drugim mierzonym parametrem mechanicznym kamieni cementowych była ich przyczepność do rur stalowych. Otrzymane wyniki badań laboratoryjnych przedstawiono w tabeli 5 oraz zobrazowano graficznie na rysunkach 5 i 6 . Badania wybranych składów wykazały, że po 7 dniach przyczepności do rur stalowych dla temperatury $25^{\circ} \mathrm{C}$ wynosity od $1,7 \mathrm{MPa}$ do 2,5 MPa, a najmocniejsza była próbka $\mathrm{nr} 39$, z zawartością $80 \%$ cementu glinowo-wapniowego G70 i $20 \%$ żużla. Po tym samym czasie spośród próbek sezonowanych $\mathrm{w} 120^{\circ} \mathrm{C}$ najmocniejsza okazała się również ta z nr. 39, a taką samą przyczepnością odznaczał się kamień cementowy wykonany ze składu nr 29 (90\% cementu glinowo-wapniowego G70 oraz 10\% mikrocementu). Oba kamienie posiadały przyczepność do rur stalowych wynoszącą 2,2 MPa.

Po 28 dniach najwyższą przyczepność do rur stalowych dla temperatury $25^{\circ} \mathrm{C}$ posiadały próbki nr 9 i 39. Pierwsza w swoim składzie miała $100 \%$ cementu G70, a jej przyczepność wyniosła 3,7 MPa, druga - 80\% cementu G70 oraz 20\% żużla, a jej przyczepność do rur stalowych wyniosła 3,5 MPa. W temperaturze $120^{\circ} \mathrm{C}$ najlepsze okazały się kamienie cementowe wykonane na samym cemencie glinowo-wapniowym G70

Tabela 5. Przyczepność kamieni cementowych do rur stalowych

Table 5. Adhesion of cement stones to steel pipes

\begin{tabular}{|c|c|c|c||c|c|c|}
\hline \multirow{3}{*}{ Skład } & \multicolumn{5}{|c|}{ Przyczepność kamienia do rur stalowych [MPa] } \\
\cline { 2 - 7 } & \multicolumn{3}{|c|}{ Temperatura 25 ${ }^{\circ} \mathbf{C}$} & \multicolumn{3}{c|}{ Temperatura 120 ${ }^{\circ}$} \\
\cline { 2 - 7 } & po 7 dniach & po 14 dniach & po 28 dniach & po 7 dniach & po 14 dniach & po 28 dniach \\
\hline \hline 9 & 2,3 & 2,8 & 3,7 & 1,9 & 2,6 & 3,5 \\
\hline 10 & 2,1 & 2,6 & 3,3 & 1,7 & 2,4 & 3,2 \\
\hline 27 & 2,0 & 2,9 & 3,0 & 2,0 & 2,8 & 3,3 \\
\hline 29 & 1,8 & 2,5 & 3,0 & 2,2 & 2,9 & 4,3 \\
\hline 31 & 1,7 & 2,6 & 3,1 & 2,1 & 2,8 & 1,8 \\
\hline 32 & 2,1 & 2,9 & 2,0 & 1,0 & 1,2 & 1,3 \\
\hline 35 & 1,9 & 2,6 & 3,4 & 1,5 & 1,8 & 3,3 \\
\hline 39 & 2,5 & 3,8 & 3,5 & 2,2 & 3,1 & 3,1 \\
\hline 40 & 2,2 & 2,8 & 3,1 & 1,8 & 2,1 & 2,6 \\
\hline
\end{tabular}

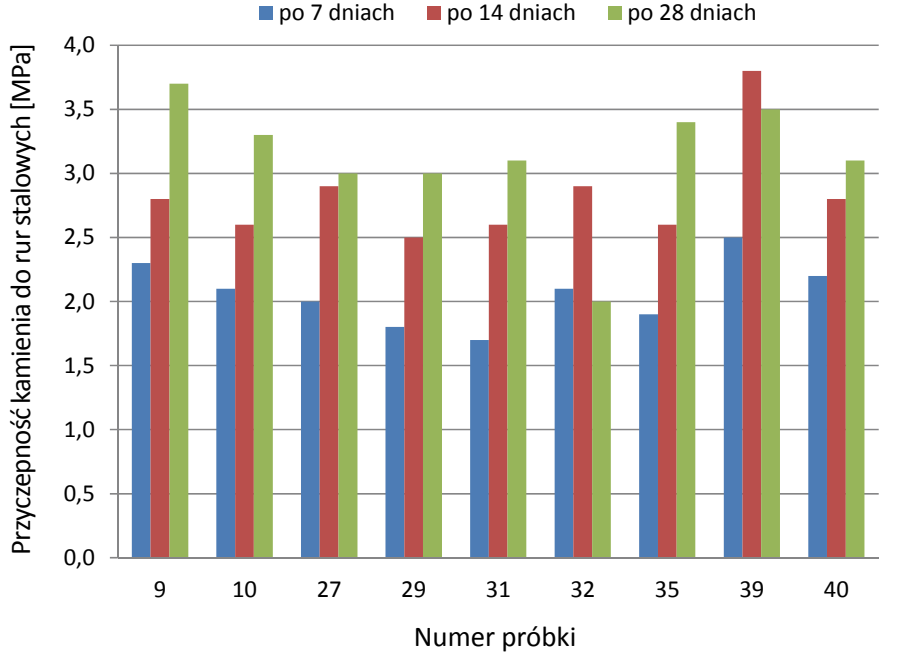

Rys. 5. Przyczepność kamieni cementowych do rur stalowych dla temperatury $25^{\circ} \mathrm{C}$

Fig. 5. Adhesion of cement stones to steel pipes at $25^{\circ} \mathrm{C}$

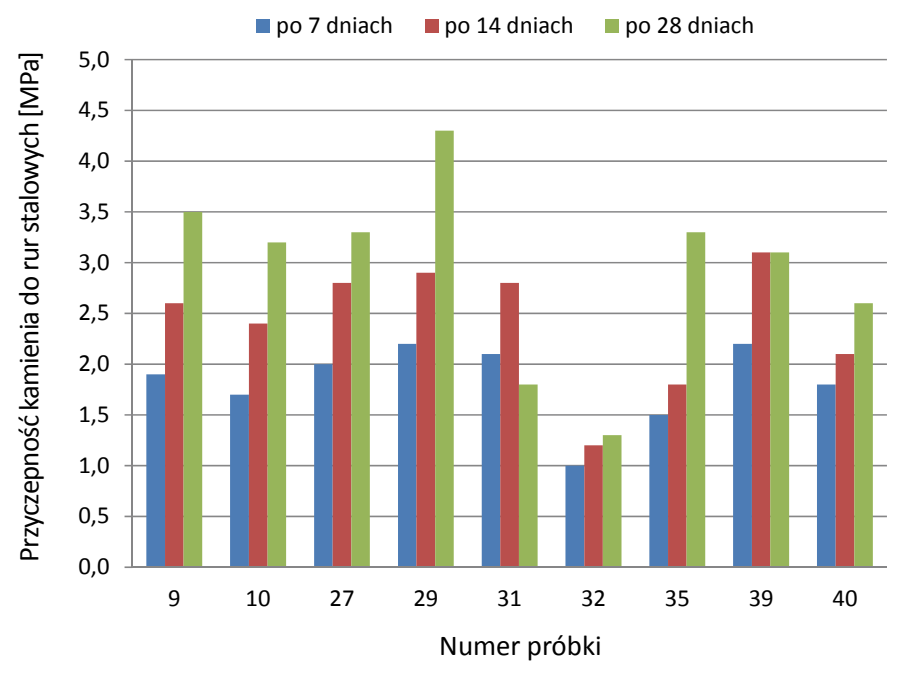

Rys. 6. Przyczepność kamieni cementowych do rur stalowych dla temperatury $120^{\circ} \mathrm{C}$

Fig. 6. Adhesion of cement stones to steel pipes at $120^{\circ} \mathrm{C}$ 
(próbka nr 9), o przyczepności 3,5 MPa, oraz o zawartości 90\% cementu G70 i 10\% mikrocementu (próbka nr 29), o przyczepności 4,3 MPa.

Ostatnim etapem badań było wykonanie pomiarów porowatości kamieni cementowych przy użyciu porozymetru rtęciowego po 28 dniach sezonowania oraz pomiarów przepuszczalności dla gazu przy użyciu przepuszczalnościomierza. Porowatości wybranych do badań próbek mieściły się w przedziale od $28,2 \%$ do $38,7 \%$. W tabeli 6 oraz na przykładowych rysunkach (rys. 7,8 ) przedstawiono wyniki badań kilku wybranych próbek kamieni cementowych. Zgodnie z pomiarami największą grupę stanowią pory z przedziału wielkości 10 000-100 nm - od 70\% do 95\%. Przepuszczalności dla gazu tych samych próbek kamieni cementowych mieściły się $\mathrm{w}$ przedziale od $0,42 \mathrm{mD}$ do $0,80 \mathrm{mD}$.

\section{Podsumowanie i wnioski}

Na podstawie przeprowadzonych badań wytypowanych składów zaczynów cementowych można wyciągnąć następujące wnioski:

1. Zawartość znacznej ilości oleju w zaczynach cementowych wpłynęła na otrzymanie niższych gęstości - od $1,625 \mathrm{~g} / \mathrm{cm}^{3}$ do $1,69 \mathrm{~g} / \mathrm{cm}^{3}$.

2. Zmierzone filtracje wynosiły od $3,0 \mathrm{~cm}^{3} / 30 \mathrm{~min}$ do $76,0 \mathrm{~cm}^{3} / 30 \mathrm{~min}$. Najwyższymi wartościami cechowały się zaczyny, w których składzie wykorzystano powszechnie stosowany cement wiertniczy G.

3. Badania wykazały, że do większych komplikacji podczas sporządzania mieszaniny dochodziło przy udziale cementu wiertniczego.

4. Użycie w składach zaczynów cementowych cementu powszechnie stosowanego powodowało ich szybkie żelowanie, oddawanie niewchłoniętej wody lub oleju w postaci odstoju.

5. Lepsze parametry posiadały zaczyny cementowe, w których zastosowano cementy glinowo-wapniowe. Zaczyny te nie posiadały odstoju lub był on bardzo niski oraz odznaczały się niskimi filtracjami.

6. Badania wykazały, że w większości przypadków połączenie składników oraz otrzymanie jednorodnej mieszaniny z cementami glinowymi było łatwiejsze niż w przypadku cementu wiertniczego.

7. Czasy końca wiązania zaczynów cementowych nie przekraczały 8 dni.

8. Zaczyny cementowe na bazie $100 \%$ cementu wiertniczego $(\mathrm{G})$ charakteryzowały się niższą elektryczną stabilnością
Tabela 6. Porowatości wybranych próbek kamieni cementowych

Table 6. Porosities of selected cement stone samples

\begin{tabular}{|c|c|c|}
\hline \multirow{2}{*}{ Nr próbki } & Porowatość & Przepuszczalność \\
\cline { 2 - 3 } & {$[\mathbf{\%}]$} & {$[\mathbf{m D}]$} \\
\hline 7 & 38,4 & 0,80 \\
\hline 8 & 36,4 & 0,64 \\
\hline 9 & 28,2 & 0,42 \\
\hline 11 & 38,7 & 0,72 \\
\hline 29 & 36,5 & 0,50 \\
\hline 35 & 36,6 & 0,48 \\
\hline
\end{tabular}

Cumulative Intrusion vs Pore size

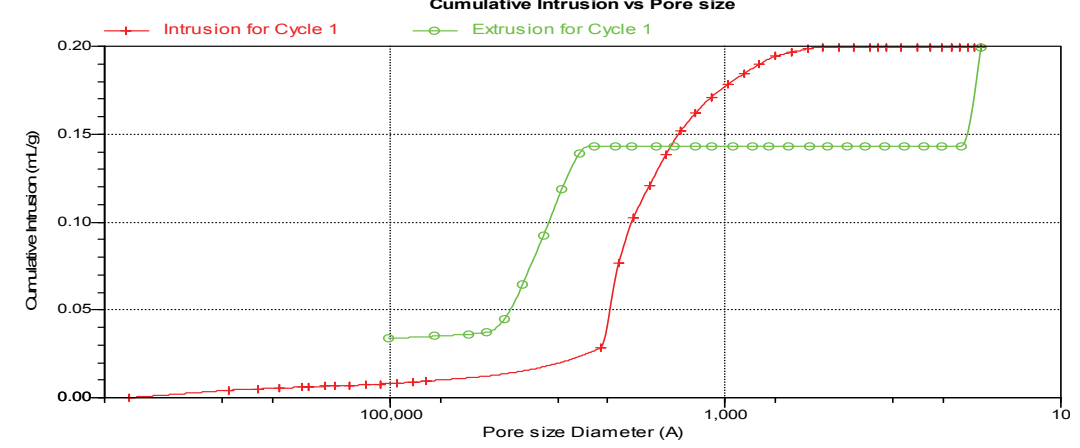

Fig. 7. Distribution of pores in sample No. 9

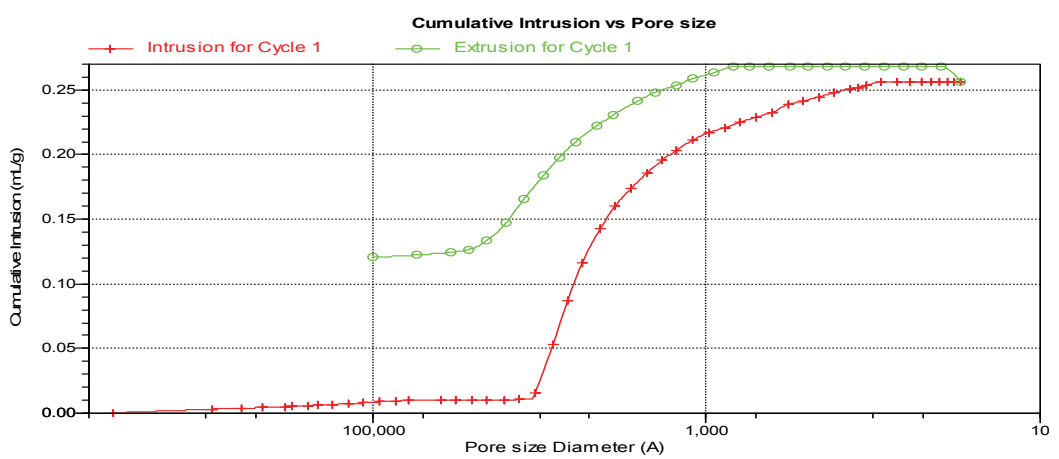

Rys. 8. Rozkład porów w próbce nr 29

Fig. 8. Distribution of pores in sample No. 29

emulsyjną (ES), poniżej 17 V. Próby mieszania tego cementu z innymi cementami (glinowo-wapniowymi) wykazały również, że wyższy wcześniej wskaźnik ES (dla tych cementów) ulegał obniżeniu oraz wzrastała filtracja tych zaczynów cementowych.

9. Zaczyny cementowe sporządzone na bazie cementów glinowo-wapniowych lub ich mieszaniny z innym spoiwem posiadały wyższe wskaźniki elektrycznej stabilności emulsyjnej, dochodzące nawet do $90 \mathrm{~V}$.

10. Badania parametrów technologicznych kamieni cementowych wykonano dla próbek zawierających cement glinowo-wapniowy lub jego mieszaninę z innym spoiwem 
ze względu na to, że posiadały one lepsze parametry reologiczne oraz wyższy wskaźnik elektrycznej stabilności emulsyjnej.

11. Najwyższe wytrzymałości na ściskanie $\mathrm{w} 25^{\circ} \mathrm{C}$ po 28 dniach otrzymano dla próbek nr 9, 29 i 35, w których składzie zastosowano cement glinowy G70. Pierwsza z nich, sporządzona na bazie samego cementu glinowo-wapniowego (100\%), posiadała wytrzymałość 17,5 MPa, druga, z domieszką mikrocementu (10\%), wytrzymałość 17,0 MPa, zaś ostatnia, z dodatkiem hematytu (20\%), 16,2 MPa.

12. W temperaturze $120^{\circ} \mathrm{C}$ najmocniejsze okazały się kamienie cementowe wykonane na samym cemencie glinowo-wapniowym G70 (próbka nr 9), o wytrzymałości 14,9 MPa, oraz na mieszaninie cementu G50 i mikrocementu (w stosunku 90\% do 10\%), o wytrzymałości 16,4 MPa (próbka nr 32).

13. Po 28 dniach najwyższą przyczepność do rur stalowych dla temperatury $25^{\circ} \mathrm{C}$ posiadały próbki nr 9 i 39. Pierwsza w swoim składzie zawierała 100\% cementu G70, a jej przyczepność wyniosła 3,7 MPa, natomiast druga - 80\% cementu G70 oraz 20\% żużla, a jej przyczepność wyniosła 3,5 $\mathrm{MPa}$.

14. W temperaturze $120^{\circ} \mathrm{C}$ najlepsze okazały się kamienie cementowe wykonane na samym cemencie glinowo-wapniowym G70 (próbka nr 9), których przyczepność wyniosła 3,5 MPa, oraz zawierające 90\% cementu G70 i 10\% mikrocementu (próbka nr 29), o przyczepności 4,3 MPa.

15. Przeprowadzone badania, otrzymane wyniki oraz dotychczasowe doświadczenia pokazują, że w zaczynach emulsyjnych opracowanych na bazie wody i oleju lepiej sprawdzają się cementy glinowo-wapniowe.

Celem badań było opracowanie emulsyjnych zaczynów cementowych typu woda w oleju o podwyższonych parametrach mechanicznych kamienia cementowego, które mogłyby znaleźć zastosowanie podczas uszczelniania kolumn rur okładzinowych po użyciu płuczki olejowodyspersyjnej.

Przeprowadzone badania nad możliwością opracowania składów zaczynów cementowych na bazie wody i oleju wykazały, że pod względem parametrów zaczynów cementowych lepszy od cementów powszechnie stosowanych w przemyśle naftowym okazał się cement glinowo-wapniowy lub jego mieszanina $z$ innym spoiwem.

Dotychczasowe badania laboratoryjne oraz analiza uzyskanych wyników wykazały, że możliwe jest sporządzenie emulsyjnych zaczynów cementowych na bazie wody i oleju o dobrych parametrach reologicznych. Również otrzymane kamienie cementowe posiadać będą dobre parametry mechaniczne oraz utworzą w otworze wiertniczym nieprzepuszczalną barierę.
Artykuł powstał na podstawie pracy statutowej pt.: Dobór materiałów wiążacych $w$ celu poprawy wytrzymałości kamieni cementowych z zaczynów emulsyjnych - praca INiG - PIB na zlecenie MNiSW; nr zlecenia: 0043/KW/2019, nr archiwalny: DK-4100-0033/2019.

\section{Literatura}

Alford P., Anderson D., Bishop M., Goldwood D., Stouffer C., Watson E., Karonka M., Moore R., 2014. Novel Oil Based Mud Additive Decreases HTHP Fluid Loss and Enhances Stability. American Association of Drilling Engineers: AADE-14-FTCE-18.

Demirdal B., Cunha J.C., 2007. Olefin Based Synthetic Drilling Fluids Volumetric Behavior Under Downhole Conditions. Society of Petroleum Engineers. DOI: 10.2118/108159-PA.

Dębińska E., 2012. Ocena działania dodatków opóźniających czas wiązania zaczynów cementowych na podstawie badań laboratoryjnych. Nafta-Gaz, 4: 225-232.

Fernandez J., Sharp K., Plummer D., 2014. Enhanced Fluid Viscosity Using Novel Surfactant Chemistry Purposely Designed for Low-Aromatic Mineral and Synthetic Base Fluids. American Association of Drilling Engineers: AADE-14-FTCE-15.

Giergiczny Z., 2003. Cementy w ofercie handlowej Górażdże Cement S.A. Chorula, październik.

Jasiński B., 2012. Badania nad zastosowaniem emulsji olejowo-wodnych jako cieczy roboczych o obniżonej gęstości. Nafta-Gaz, 12: 1155-1164.

Kurca O., Yaman İ.Ö., Tokyay M., 2013. Compressive strength development of calcium aluminate. Cement and Concrete Composites, 35(1): 163-170. DOI: 10.1016/j.cemconcomp.2012.08.016.

Kremieniewski M., 2012. Modyfikacja przestrzeni porowej kamieni cementowych. Nafta-Gaz, 3: 165-170.

Kremieniewski M., 2013. Wpływ warunków hydratacji na strukturę przestrzenną kamieni cementowych. Nafta-Gaz, 1: 51-56.

Kurdowski W., 2010. Chemia cementu i betonu. Wydawnictwo Naukowe PWN, Warszawa.

Kut Ł., 2011. Wpływ mikrocementu na parametry zaczynu i kamienia cementowego. Nafta-Gaz, 12: 903-908.

Li Z., Cheng X., Zhang M., Wu X., Wu S., Wu D., Xiao Y., 2016. The Research and Application about Aluminate Cement Slurry in Heavy Oil Thermal Well. Society of Petroleum Engineers. DOI: 10.2118/182514-MS.

Maghrabi S., Wagle V., Teke K., Kulkarni D., Kulkarni K., 2011. Low Plastic Viscosity Invert Emulsion Fluid System for HPHT Wells. American Association of Drilling Engineers: AADE-11-NTCE-15.

Vipulanandan C., Krishnamoorti R., 2013. Smart cementing materials and drilling muds for real time monitoring of deepwater wellbore enhancement. CIGMAT University of Houston.

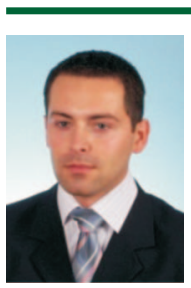

Mgr inż. Łukasz KUT

Asystent w Zakładzie Technologii Wiercenia Instytut Nafty i Gazu - Państwowy Instytut Badawczy ul. Lubicz 25 A

31-503 Kraków

E-mail:lukasz.kut@inig.pl 